\title{
Effect of temperament of ewes on their maternal ability and their lambs' postweaning traits in Tsigai breed
}

\author{
FERENC PAJOR, ANNAMÁRIA MURÁNYI, ANDREA SZENTLÉLEKI, JÁNOS TŐZSÉR and \\ PÉTER PÓTI
}

Institute of Animal Husbandry, Szent Istvan University, Hungary

\begin{abstract}
The aims of present study were to investigate the relationship between temperament score and cortisol and lactic acid levels of blood, as well as the effect of temperament on the maternal ability traits (milk production, lamb preweaning gain) and the postweaning growth of lambs in Tsigai breed. The temperament of thirty-one Tsigai ewes was scored by the temperament score test (behaviour of animals was assessed in a 5-score system (1: calm, 5: nervous) while spending $30 \mathrm{~s}$ on the scale during weighing), in addition, the cortisol level and the lactic acid concentration of blood were measured at weaning. The weaning weight, temperament, cortisol concentration, the pre- and the postweaning weight gain of lambs were also investigated in this study. The cortisol level and lactic acid concentration were highly related to the temperament scores of ewes $\left(r_{\text {rank }}=0.79, P<0.001 ; r_{\text {rank }}=0.53, P<0.01\right)$. The calmer ewes had a lower cortisol $(1.79 \mathrm{nmol} / \mathrm{l}, P<0.001)$ and lactic acid $(1.87 \mathrm{mmol} / \mathrm{l}, P<0.01)$ concentration compared to the results of nervous ewes $(5.35 \mathrm{nmol} / \mathrm{l}, 3.11 \mathrm{mmol} / \mathrm{l}, \mathrm{resp}$.). It was statistically proven $(P<0.01)$ that the calm ewes' lambs had higher preweaning weight gain $(244.0 \mathrm{~g} / \mathrm{day})$ and weaning weight $(22.0 \mathrm{~kg})$ than nervous animals $(201.7 \mathrm{~g} / \mathrm{day}, 18.1 \mathrm{~kg})$. In addition, the calm ewes milked by hand produced more milk $(52.4 \mathrm{I}, P<0.05)$ than nervous ewes $(46.1 \mathrm{I})$ in the milking period. Furthermore, the calm ewes' lambs had lower temperament score and cortisol concentration and better fattening performance than lambs were originated from nervous ewes.
\end{abstract}

Keywords: temperament, cortisol concentration, lamb rearing, milk production, Tsigai

\section{Zusammenfassung}

\section{Einfluss des Temperamentes von Zackelschafen auf ihre Mütterlichkeit und die Aufzuchtleistung ihrer Lämmer nach dem Absetzen}

Untersucht wurden bei 31 Zackelschafmüttern deren Temperament, die Kortisol- und Milchsäurekonzentration des Blutes sowie die Muttereigenschaften beurteilt nach der Milchleistung, der Lebenstagszunahme der Lämmer vor und nach dem Absetzen dieser. Sowohl die Blutkennwerte als auch der Temperamenttest der Mütter und Lämmer erfolgte bei der Tierwägung, wobei in einem Zeitraum von 30 Sekunden das Verhalten nach einem 5-Punktesystem (1=ruhig, 5=nervös) bewertet wurde. Sowohl bei der Kortisol- als auch der Milchsäurekonzentration ergaben sich bei den Müttern signifikante Rangkorrelationen zu den Temperamentpunktzahlen $\left(r_{\text {rank }}=0,79\right.$ bzw. $\left.r_{\text {rank }}=0,53\right)$. Die Kortosol- bzw. Milch- 
säurespiegel erreichten bei den ruhigen Tieren (1) Werte von 1,79 nmol/l bzw. 1,87 mmol// und bei den nervösen Tieren (4+5) 5,35 nmol// bzw. 3,11 mmol/l. Lämmer der ruhigen Mütter erreichten sowohl vor (244 g/Tag) als auch nach dem Absetzen (22,0 kg Lämmergewicht) signifikant höhere Gewichtszunahmen als die nervösen Mütter $(201 \mathrm{~g} / \mathrm{Tag}, 18,1 \mathrm{~kg})$. Die Handmelkergebnisse während der Melkperiode unterschieden sich signifikat zugunsten der ruhigen Tiere (52,4 I bzw. 46,1 I). Die Lämmer der ruhigen Mütter erreichten geringere Temperamentpunkte, geringere Kortisolwerte und besseren Tageszunahmen als die Lämmer der nervösen Mütter.

Schlüsselwörter: Temperament, Kortisolkonzentration, Lämmeraufzucht, Milchproduktion, Zackelschaf

\section{Introduction}

The maternal ability traits (e.g. lamb rearing, milk production) are very important for sheep breeders. These traits are influenced by some factors such as maternal behaviour, which is determined by the subjective assessment for example the maternal behaviour score test (O'CONNOR et al. 1985) and the temperament test (MURPHY et al. 1994) too. Temperament is defined as the animal's behavioural response to handling by humans (BURROW 1997). Temperament seems to improve some production traits such as growth rate (in cattle: VOISINET et al. 1997, FELL et al. 1999, in sheep: PAJOR et al. 2008), immune function (in cattle: FELL et al. 1999, in sheep: IVANOV et al. 2005) and meat quality (in cattle: NEINDRE et al. 1996, REVERTER et al. 2003). STRITTMATTER (2001) described a lot of differences between sheep races in the activity of behaviour. In addition races are different in the social behaviour too (GRÄSER-HERMANN and SAMBRAUS 2001).

Some authors (O'CONNOR et al. 1985, LAMBE et al. 2001, EVERETT-HINKS et al. 2005) reported that the maternal behaviour score has been shown to be related to both postnatal lamb survival and weaning weight. In case of temperament, MURPHY et al. (1994) and NEINDRE et al. (1998) published that mortality of lambs attributable to poor maternal behaviour was higher for the temperamental animals compared to the calmer line (18vs. $6 \%)$. The fertility between calm and nervous ewes was significantly different $(P<0.05)$ at the age of three years (IVANOV and DJORBINEVA 2003).

Several studies have reported positive relationships between dairy temperament score and milk production traits in cows. MUSHRA et al. (1975), ARAVE and KILGOUR (1982) revealed that a linear relationship stands between temperament score and daily and total milk yields, but the relationship with lactation length was not clear. In sheep a few studies have found relationship between temperament and milk production. For example IVANOV and DJORBINEVA (2003) found that the calm ewes produced more milk by machine milking $(P<0.05)$ than nervous animals during the whole milking period.

Although, the majority of studies reports positive relationships between maternal behaviour (e.g. temperament score) and postnatal lamb mortality and weaning weight, it is not known whether the relationship exists between the ewes' temperament and their lambs' temperament and postweaning growth traits.

This study's aim was to investigate the relation between temperament score and cortisol level, and to measure the effect of ewes' temperament on the maternal ability traits 
(milk production, lamb preweaning gain), and the postweaning growth traits of lambs in Tsigai (Hungarian native) (KUSZA et al. 2009) breed.

\section{Materials and methods}

\section{Experimental design}

The study was carried out in the Sheep Farm in Solt (Bács-Kiskun County, Hungary). 31 Tsigai ewes and their 31 lambs were examined maternal ability traits (milk production and lamb preweaning gain) (1st investigation) and 31 lambs were participant in Own Performance Test (2nd investigation). From these lambs were randomly selected 20 lambs for blood parameters determination. All ewes were lambed just a live lamb. The health condition and nutritional status of animals were good during the experimental period included two investigations.

\section{First Investigation}

At weaning was studied the temperament score of 31 Tsigai ewes (mean age: 4.7 year; mean number of lambing: 3.4 pieces) and cortisol and lactic acid concentration of blood were determined, in addition was measured their lambs' $(n=31)$ preweaning weight gain and weaning weight. The average age of the lambs was 88 day at weaning. By the results of weighing, the body weight was adjusted to average 90 days of age by using a linear interpolation method. All lambs originated from one sire. After weaning the ewes were milked by hand during the lactation period of 106 days (from 15th April to 30th July). The animals were kept from weaning to end of the lactation period on pasture and supplement fed alfalfa hay and concentrate mix (about $300 \mathrm{~g} /$ day) given at milking (attractive concentrate). Before weaning the ewes fed ad libitum meadow hay and concentrate mix ( $300 \mathrm{~g})$.

\section{Second Investigation}

After weaning (on-test day) the growth investigation of lambs $(n=31)$ was studied in the Own Performance Test for 41 days (off-test day). Under performance test the lambs were given ad libitum water and concentrate mix ( $150 \mathrm{~g} / \mathrm{kg}$ DM crude protein and $7.20 \mathrm{MJ} / \mathrm{kg} \mathrm{DM}$ and $4.80 \mathrm{MJ} / \mathrm{kg} \mathrm{DM}$ net energy $\left(\mathrm{NE}_{\mathrm{m}}\right.$ and $\mathrm{NE}_{\mathrm{g}}$ ). Each lamb was weighed individually with the precision of $0.1 \mathrm{~kg}$ at weaning and at the end of the test. Daily weight gain was calculated in grams. At weaning and at the end of the test the temperament of lambs was evaluated by temperament score test and from these animals were randomly selected 20 lambs and blood samples were collected and level of cortisol was determined.

\section{Temperament test}

Temperament was measured according to the temperament score test by TRILLAT et al. (2000). Behaviour of animals was assessed in a 5-score system at weighing, while spending 30 s on the scale:

1 calm, no movement,

2 calm with occasional movements,

3 calm with some more movements but without shaking the scale, 
4 abrupt episodic movements without shaking the scale,

5 permanent episodic movements and shaking the scale.

\section{Analytical procedures}

Blood samples collected from 31 Tsigai ewes at weaning and from 20 lambs at on- test (weaning, 0. day) and at off-test (41. day) between 8.00-9.00 from v. jugularis into tubes containing heparin. The blood sampling held approx. 0.5-1 min per animal. Then they were immediately transported to the laboratory and centrifuged at $3500 \mathrm{l} / \mathrm{min}$ for $10 \mathrm{~min}$. The plasma was stored at $-70^{\circ} \mathrm{C}$ until further analyses.

\section{Cortisol assay}

For the cortisol assay a direct radioimmunoassay method, developed in the laboratory of Szent Istvan University, Faculty for Veterinary Science (Budapest, Hungary) was applied. For determination in blood plasma using 1,2,6,7-3H-cortisol (TRK 407; Radiochemical Centre, Amersham, UK) and a highly specific polyclonal antibody raised against cortisol-21-HS-BSA in rabbit was used. Radioactivity was measured by Tri-Carb 2800TR (Perkin-Elmer) liquid scintillation counter. The sensitivity of this assay system was $11.37 \mathrm{fmol} /$ tube. Within the concentration range of about 2.00 and $100.00 \mathrm{nmol} / \mathrm{ml}$ the intra- and interassay coefficients of variation varied between $3-8 \%$ and $5-10 \%$, respectively in all species. Samples with cortisol level being higher than $100.00 \mathrm{nmol} / \mathrm{l}$ had to be re-assayed after dilution.

\section{Lactic acid assay}

The lactic acid was analysed by enzymatic method using commercial kits (Lactate PAP, BioMerieux, Marcy-l'Etoile, France).

\section{Statistical analysis}

Statistical analysis was processed by SPSS 14.0 program package (Levene's test for equality of Variances, ANOVA test, Tukey test, Kruskal-Wallis test, Pearson simple- and Spearmancorrelation).

\section{Results}

Based on the temperament ranking, 13 ewes were into the calm category ( 1 score), 11 ewes were into the average ( 2 and 3 scores) and 7 ewes were into the nervous ( 4 and 5 scores) category. Results of maternal ability traits, cortisol and lactic acid levels of Tsigai ewes according to the temperament category are demonstrated in Table 1.

The mean number of lambing was 3.4 and mean age was 4.7 years. Among temperament categories were not detected differences in ewes' mean number of lambing and the mean age. The blood parameters, cortisol and lactic acid showed differences among temperament categories. Positive correlation found between the ewes' cortisol level and temperament score $\left(r_{\text {rank }}=0.79, P<0.001\right)$ and lactic acid level and temperament score $\left(r_{\text {rank }}=0.53, P<0.01\right)$. The calmer ewes had a lower cortisol $(1.79 \mathrm{nmol} / \mathrm{l}, P<0.001)$ and lactic acid $(1.87 \mathrm{mmol} / \mathrm{l}$, 
$P<0.01)$ concentration compared to the nervous ewes $(5.35 \mathrm{nmol} / \mathrm{l}, 3.11 \mathrm{mmol} / \mathrm{l})$, respectively. Among temperament categories were differences in the ewes' lamb preweaning weight gain and weaning weight (at the 90th day of age). The maternal temperament score showed to be related to preweaning weight gain and weaning weight. The calmer ewes' lambs had higher $(P<0.01)$ preweaning weight gain $(244.04 \mathrm{~g} /$ day) and higher $(P<0.01)$ weaning weight $(21.97 \mathrm{~kg})$ compared to nervous ewes' lambs (200.73 g/day and $18.07 \mathrm{~kg})$, respectively.

Table 1

Maternal ability traits and some blood parameters of Tsigai ewes by temperament categories (mean \pm SD) Muttereigenschaften und Blutparameter nach Temperamentkategorien bei Zackelschafmüttern

\begin{tabular}{lcccc}
\hline Parameters & \multicolumn{1}{c}{ Calm $^{1}$} & Average $^{2+3}$ & Nervous $^{4+5}$ & $P<$ \\
\hline $\mathrm{n}$ & 13 & 11 & 7 & \\
Number of lambing & $3.40 \pm 1.35$ & $3.27 \pm 0.90$ & $3.57 \pm 0.98$ & $\mathrm{~ns}$ \\
Age, year & $4.56 \pm 1.51$ & $4.65 \pm 1.15$ & $4.92 \pm 0.78$ & $\mathrm{~ns}$ \\
Cortisol, $\mathrm{nmol} / \mathrm{l}$ & $1.79 \pm 0.60^{\mathrm{A}}$ & $3.21 \pm 0.45^{\mathrm{a}}$ & $5.35 \pm 1.05^{\mathrm{Aa}}$ & 0.001 \\
Lactic acid, mmol/l & $1.87 \pm 0.67^{\mathrm{A}}$ & $2.44 \pm 0.81$ & $3.11 \pm 0.79^{\mathrm{A}}$ & 0.01 \\
Lamb preweaning & & & & \\
weight gain, g/day & $244.04 \pm 21.9^{\mathrm{A}}$ & $234.81 \pm 29.59$ & $200.73 \pm 17.4^{\mathrm{A}}$ & 0.01 \\
Lamb weight at on-test & & & & \\
(weaning), kg & $21.97 \pm 1.98^{\mathrm{A}}$ & $21.13 \pm 2.66$ & $18.07 \pm 1.58^{\mathrm{A}}$ & 0.01 \\
Total milk production, I & $52.44 \pm 5.34^{\mathrm{a}}$ & $49.67 \pm 3.86$ & $46.06 \pm 5.34^{\mathrm{a}}$ & 0.05 \\
Daily milk yield, I & $0.49 \pm 0.04^{\mathrm{a}}$ & $0.47 \pm 0.04$ & $0.44 \pm 0.05^{\mathrm{a}}$ & 0.05 \\
\hline
\end{tabular}

${ }^{1}$ calm, no movement, ${ }^{2}$ calm with occasional movements, ${ }^{3}$ calm with some more movements but without shaking the scale, ${ }^{4}$ abrupt episodic movements without shaking the scale, ${ }^{5}$ permanent episodic movements and shaking the scale, ${ }^{a} P<0.05,{ }^{A} P<0.01$, ns not significant

After weaning, the ewes were milked by hand. The lactation period was 106 day (from 15th April - to 30th July). The calmer ewes had higher $(P<0.05)$ total milk production $(52.44 \mathrm{I})$ and higher $(P<0.05)$ daily milk yield $(0.49 \mathrm{l} /$ day) compared to nervous animals ( $46.06 \mathrm{I}$ and $0.44 \mathrm{l} /$ day).

The results of temperament scoring and the fattening traits of Tsigai lambs are presented in Table 2.

Table 2

Temperament scoring and the fattening traits of Tsigai lambs by gender (mean \pm SD) Temperamentpunktzahl und Masteigenschaften bei Zackelschaflämmern beider Geschlechter

\begin{tabular}{lcccccc}
\hline Items & $\mathrm{n}$ & $\begin{array}{c}\text { Weaning } \\
\text { weight, } \mathrm{kg}\end{array}$ & $\begin{array}{c}\text { Off-test } \\
\text { weight, } \mathrm{kg}\end{array}$ & $\begin{array}{c}\text { Average daily } \\
\text { gain, } \mathrm{g} / \text { day }\end{array}$ & $\begin{array}{c}\text { Temperament } \\
\text { score at on-test }\end{array}$ & $\begin{array}{c}\text { Temperament } \\
\text { score at off-test }\end{array}$ \\
\hline Ram & 16 & $20.75 \pm 2.12$ & $37.78 \pm 2.53$ & $427.46 \pm 42.90$ & $2.69 \pm 1.01$ & $2.44 \pm 0.73$ \\
Ewe & 15 & $19.89 \pm 1.93$ & $37.56 \pm 1.85$ & $416.14 \pm 88.12$ & $2.40 \pm 1.06$ & $2.60 \pm 0.63$ \\
$P$ & & $\mathrm{~ns}$ & $\mathrm{~ns}$ & $\mathrm{~ns}$ & $\mathrm{~ns}$ & $\mathrm{~ns}$ \\
\hline
\end{tabular}

ns not significant

The results showed no differences in temperament and weight gain between the two sexes in the present sample. Therefore the two data were contracted in this study.

If lambs were categorised by the temperament of ewes, there were confirmed significant differences among lamb groups concerning the lamb off-test weight, postweaning gain, temperament score and cortisol concentration (Table 3). 
Table 3

Fattening traits, temperament score and cortisol concentration of lambs by temperament categories of Tsigai ewes (mean \pm SD)

Masteigenschaften und Kortisolkonzentration der Lämmer nach Temperamentkategorien der Mütter

\begin{tabular}{|c|c|c|c|c|c|c|c|c|}
\hline Parameters & \multicolumn{3}{|c|}{ Calm $^{1}$} & \multicolumn{2}{|c|}{ Average $^{2+3}$} & \multicolumn{2}{|c|}{ Nervous ${ }^{4+5}$} & \multirow[t]{2}{*}{$P<$} \\
\hline$n=31$ & & 13 & & & 11 & & 7 & \\
\hline $\begin{array}{l}\text { Lamb weight } \\
\text { at off-test, kg }\end{array}$ & 39.33 & \pm & $1.59 a$ & 38.44 & \pm 2.45 & 34.64 & $\pm 4.12 \mathrm{a}$ & 0.05 \\
\hline $\begin{array}{l}\text { Postweaning weight } \\
\text { gain, g/day }\end{array}$ & 464.90 & \pm & $29.81 \mathrm{Aa}$ & 400.00 & $\pm 39.18 a$ & 385.80 & $\pm 52.49 \mathrm{~A}$ & 0.01 \\
\hline $\begin{array}{l}\text { Lamb temperament } \\
\text { score at on-test }\end{array}$ & 2.63 & \pm & 0.74 & 2.60 & $\pm \quad 1.14$ & 2.43 & $\pm \quad 0.79$ & ns \\
\hline $\begin{array}{l}\text { Lamb temperament } \\
\text { score at off-test }\end{array}$ & 2.13 & \pm & $0.35 \mathrm{~A}$ & 2.60 & \pm 0.55 & 3.14 & $\pm 0.69 \mathrm{~A}$ & 0.01 \\
\hline$n=20$ & & 8 & & & 5 & & 7 & \\
\hline $\begin{array}{l}\text { Lamb cortisol } \\
\text { at on-test, nmol// }\end{array}$ & 2.16 & \pm & 1.46 & 1.91 & \pm 1.23 & 2.13 & \pm 1.18 & ns \\
\hline $\begin{array}{l}\text { Lamb cortisol } \\
\text { at off-test, nmol/l }\end{array}$ & 2.81 & \pm & $1.71 a$ & 3.69 & \pm 2.03 & 5.86 & $\pm 2.51 a$ & 0.05 \\
\hline $\begin{array}{l}\text { Lamb cortisol } \\
\text { change, } \%\end{array}$ & 30.25 & \pm & $83.41 a$ & 93.03 & \pm 82.75 & 173.54 & \pm 98.91a & 0.05 \\
\hline
\end{tabular}

${ }^{1}$ calm, no movement, ${ }^{2} \mathrm{calm}$ with occasional movements, ${ }^{3} \mathrm{calm}$ with some more movements but without shaking the scale, ${ }^{4}$ abrupt episodic movements without shaking the scale, ${ }^{5}$ permanent episodic movements and shaking the scale, ${ }^{a} P<0.05,{ }^{A} P<0.01$, ns not significant

The lambs from calm ewes showed higher off-test weight $(39.3 \mathrm{~kg})$ and average daily weight gain $(464.9 \mathrm{~g} /$ day) and had lower temperament score at off-test (2.13) compared to lambs from nervous ewes $(34.6 \mathrm{~kg}, P<0.05 ; 385.8 \mathrm{~g} / \mathrm{day}, P<0.01 ; 3.14, P<0.01)$. Furthermore, the lambs from calm ewes had lower cortisol concentration values at the off-test $(2.81 \mathrm{nmol} / \mathrm{l})$ and incremental change $(30.25 \%)$ compared to the lambs from nervous ewes $(5.86 \mathrm{nmol} / \mathrm{l}$ and $173.54 \%$ ), respectively.

Relationship between ewe's cortisol level, temperament score and their lambs' cortisol level, temperament and fattening traits are represented in Table 4.

Table 4

Pearson and Spearman correlation among maternal cortisol concentration and temperament score and fattening traits, temperament and cortisol level of lambs $(\mathrm{n}=31)$

Pearson und Spearman Korrelationen zwischen Kortisolkonzentration (MC) und Temperamentpunkten (MT) der Mütter sowie den untersuchten Lämmermerkmalen

\begin{tabular}{lcccccc}
\hline Traits & $\begin{array}{c}\text { Weight gain, } \\
\text { under life time }\end{array}$ & $\begin{array}{c}\text { Postweaning } \\
\text { weight gain }\end{array}$ & $\begin{array}{c}\text { Weight } \\
\text { at off-test }\end{array}$ & $\begin{array}{c}\text { Temperament } \\
\text { score at off-test }\end{array}$ & $\begin{array}{c}\text { Cortisol } \\
\text { at off-test }\end{array}$ & $\begin{array}{c}\text { Cortisol } \\
\text { change }^{*}\end{array}$ \\
\hline $\mathrm{MC}\left(\mathrm{r}_{\mathrm{p}}\right)$ & -0.44 & -0.52 & -0.44 & 0.71 & 0.57 & 0.68 \\
$P<$ & 0.05 & 0.05 & 0.05 & 0.001 & 0.01 & 0.001 \\
$\mathrm{MT}\left(\mathrm{r}_{\mathrm{s}}\right)$ & -0.48 & -0.53 & -0.45 & 0.55 & 0.43 & 0.57 \\
$P<$ & 0.05 & 0.05 & 0.05 & 0.01 & 0.05 & 0.01 \\
\hline
\end{tabular}

$r_{p}$ Pearson correlation, $r_{s}$ Spearman correlation, MC maternal cortisol concentration, MT temprament score, ${ }^{*} n=20$ 
Moderate, negative correlation was between ewes' cortisol level and temperament score with the lambs' weight gain under life time (from birth to end of test) ( $r=-0.44$ and $r=-0.48$ ), and under test period (from 90th to 131st day) ( $r=-0.52$ and $r=-0.53$ ) and finally, the off-test weight $(r=-0.44$ and $r=-0.45)$, respectively. Positive, significantly correlation found between the ewes' cortisol level and temperament score with the lambs' temperament score $(r=0.71$ and $r=0.55)$ and the lambs' cortisol level at the off-test $(r=0.57$ and $r=0.43)$ and incremental change in cortisol ( $r=0.68$ and $r=0.57)$.

\section{Discussion}

The cortisol concentration may depend on sampling circumstances. Particular treatment can be measured if a blood sample is collected within 2 min of the beginning of the blood sampling procedure (BROOM and JOHNSON 1993). The sampling procedure is hold less than 2 min, therefore the sampling circumstances are not modified the characteristic cortisol values of animals. The cortisol and lactic acid concentration were highly related to ewes' temperament score. The calm ewes had a lower cortisol and lactic acid level compared to the nervous animals. This result suggested that the temperamental animal exhibit increased stress responsiveness to handling, increased the adrenal function and, in this way, the baseline cortisol concentration. The hypothalamic-pituitary-adrenal (HPA) axis, through the cortisol concentration, affects the animals' metabolism. If an animal has higher cortisol concentration (e.g. induced by a stressor), the biological response includes alterations in the neuroendocrine system, in the autonomic nervous system, in the immune system and also in the animal's behaviour (MANTEUFFEL and PUPPE 1997, MOBERG 2000) by altering the function of the HPA axis (GUPTA et al. 2004). One of the biological responses is to increase metabolic rate because of increased catabolic processes (BROCKMAN and LAARVELD 1986). Other responses to stress include behavioural changes, such as increased activity (LUITING et al. 1994). In the present sample, nervous ewes had higher lactic acid level of blood than calm ewes. Because, the locomotory activity is affect the muscle contraction. Higher muscle contraction leads to higher lactic acid concentration in the blood (lactic acid concentration is affected by muscle contraction). The adjustment to stress induces a broad range of neuroendocrine, physiological and behavioural changes to allow for adaptation to the change (BORELL 2000, TUCHSCHERER and MANTEUFFEL 2000). MANTEUFFEL (2002) summarising the regulation of HPA axis and its impact on metabolism and animal welfare. An animal's total body response to stress can be measured through decreased rates of growth and decreased efficiency of nutrient utilisation (e.g. residual feed intake) (KNOTT et al. 2007), and a subsequent increase in the energetic cost of the animal. Decreased nutrient utilisation is likely to go less with milk production, which leads to lower preweaning weight gain and weaning weight. Milk production of ewes has an important effect on the preweaning survival and growth of their lambs. The present results showed that, after weaning, calm ewes produced more milk than nervous ewes. These results were corresponded with results of IVANOV and DJORBINEVA (2003).

In the present sample, not found differences in temperament and weight gain between the two sexes, although SAVAS et al. (2001) found great differences between males and females in behaviour abnormalities.

However, the maternal temperament not related with lambs' temperament and cortisol 
concentration at on-test (weaning), but the mothers' temperament has great effect on lambs' temperament at off-test, pre- and postweaning growth traits, because, as expected, before weaning, lambs weight and behaviour are influenced by maternal factors, mainly mother milk production and mother-lamb bond. After weaning, the new circumstances and environments (such as miss of dam, restriction of space in the fattening) should be a cause of stress for lambs. Metabolic rate, behaviour and growth of animals could be influenced by the HPA axis. In the present sample, those lambs which originated from calm ewes had lower temperament score and incremental cortisol change and higher postweaning weight gain. These data refer that there are a medium strong, significant, negative relationship between ewes' temperament (and cortisol concentration) and their lambs' postweaning growth traits and weight gain under life time. Similar results were reported by LAMBE et al. (2001) who estimated a moderate, positive genetic correlation (0.4) between maternal behaviour score (1-5 score, 1: poor mothers; 5: excellent mothers) and the average weight gained by lambs from birth to marking. This means that calm lambs (those with low score) may grow faster in a feedlot period than nervous (temperamental) lambs (those with high score). It is highly probable that the higher growth rate of calm lambs results from maybe an increased feed intake and better nutrient utilization, although the probability that the nervous animals using more energy in avoidance-type behaviour should not be ignored (BURROW and DILLON 1997).

Summarising the results, this study suggested that the more temperamental (nervous) ewes produced less milk under milking period, and these ewes' lambs have lower preweaning weight gain and weaning weight compared with calm ewes. Finally, the calm ewes' lambs will have been calmer and higher fattening performance than those lambs which is originated from nervous mothers. These results indicate that temperament test application is positive benefits for sheep breeders, e.g. calm animals can reduce fattening period and produce more milk.

\section{Acknowledgements}

We appreciate and we would like to say thank for assistance (cortisol determination) of Prof. Dr. Gyula Huszenicza (Szent Istvan University, Faculty of Veterinary Science).

\section{References}

Arave CW, Kilgour R (1982) Differences in grazing and milking behaviour in high and low breeding index cows. Proc New Zeal Soc Anim Prod 42, 65-7

Borell von E (2000) Stress and coping in farm animals. Arch Tierz 43, Special Issue, 144-52

Brockman RP, Laarveld B (1986) Hormonal regulation of metabolism in ruminants; a review. Livest Prod Sci 14, 313-34

Broom DM, Johnson KG (1993) Stress and Animal Welfare. Chapman and Hall, London In: Manteca X (1998) Neurophysiology and Assessment of Welfare. Meat Sci 49, Suppl. 1, 205-18

Burrow HM, Dillon RD (1997) Relationship between temperament and growth in a feedlot and commercial carcass traits of Bos indicus crossbreds. Aust J Exp Agric 37, 400-11

Burrow HM (1997) Measurement of temperament and their relationship with performance traits of beef cattle. Anim Breed Abstr 65, 478-95 
Everett-Hinks JM, Blair HT, Stafford KJ, Lopez-Villalobos N (2005) Effect of ewe maternal behaviour score on lamb survival and litter survival. Livest Prod Sci 93, 51-61

Fell LR, Colditz IG, Walker KH, Watson DL (1999) Associations between temperament, performance and immune function in cattle entering a commercial feedlot. Aust J Exp Agric 39, 795-802

Gupta S, Earley B, Ting STL, Leonard N, Crowe MA (2004) Technical note: effect of corticotropin-releasing hormone on adrenocorticotropic hormone and cortisol in steers. J Anim Sci 82, 1952-6

Gräser-Hermann C, Sambraus HH (2001) The social behaviour of East Friesian dairy sheep in larger groups. Arch Tierz 44, 421-33

Ivanov ID, Djorbineva M (2003) Assessment of welfare, functional parameters of the udder, milk productive and reproductive traits in dairy ewes of different temperament. Bulg J Agric Sci 9, 711-5

Ivanov ID, Djorbineva M, Sotirov L, Tanchev S (2005) Influence of fearfulness on lysozyme and complement concentrations in dairy sheep. Revue Méd Vét 156, 445-8

Knott SA, Cummins LJ, Dunshea FR, Leury BJ (2007) Rams with poor feed efficiency are highly responsive to an exogenous adrenocorticotropin hormone (ACTH) challenge. Domest Anim Endrocrinol 34, 261-8

Kusza, S, Nagy, I, Nemeth T, Molnar A, Javor A, Kukovics S (2009) The genetic variability of Hungarian Tsigai sheep. Arch Tierz 53, 309-17

Lambe NR, Conington J, Bishop SC, Waterhouse A, Simm G (2001) A genetic analysis of maternal behaviour score in Scottish Blackface sheep. Anim Sci 72, 415-25

Luiting P, Urff EM, Verstegen MWA (1994) Between-animal variation in biological efficiency as related to residual feed consumption. Neth J Agric Sci 42, 59-67

Manteuffel G (2002) Central nervous regulation of the hypothalamic-pituitary-adrenal axis and its impact on fertility, immunity, metabolism and animal welfare - a review. Arch Tierz 45, 575-95

Manteuffel G, Puppe B (1997) Is it possible to judge the subjective perception of internal State in animals? A critical analysis from a scientific point of view. Arch Tierz 40, 109-21 [in German]

Moberg GP (2000) Biological response to stress: implications for animal welfare. In: Moberg, GP, Mench, JA, editors. The biology of animal stress: basic principles and implications for animal welfare. CABI Publishing, $1-22$

Murphy PM, Lindsay DR, Purvis IW (1994) The importance of the birth site on the survival of Merino lambs. Proc Aust Soc Anim Prod 20, 251-54

Mushra RR, Chauhan RS, Gupta SC (1975) Studies of dairy temperament of Karan Swis Cows, Indian J Dairy Sci $28,85-8$

Neindre PL, Boivin X, Boissy A (1996) Handling of extensively kept animals. Appl Anim Behav Sci 49, 73-81

Neindre PL, Murphy PM, Boissy A, Purvis IW, Lindsay D, Orgeur P, Bouix J, Bibe B, Neindre LP (1998) Genetics of maternal ability in cattle and sheep. Proceedings of the 6th World Congress on Genetics Applied to Livestock Production, Armidale, Australia January 11-16. 27, 23-30

O'Connor CE, Jay NP, Nicol AM, Beatson PR (1985) Ewe maternal behaviour score and lamb survival. Proc New Zealand Soc Anim Prod 45, 159-62

Pajor F, Szentléleki A, Láczó E, Tőzsér J, Póti P (2008) The effect of temperament on weight gain of Hungarian Merino, German Merino and German Blackhead lambs. Arch Tierz 51, 247-54

Reverter A, Johnston DJ, Ferguson DM, Perry D, Goddard ME, Burrow HM, Oddy VH, Thompson JM, Bindon BM (2003) Genetic and phenotypic characterisation of animal, carcass and meat quality traits from temperate and tropically adapted beef breeds. 4. Correlations among animal, carcass and meat quality traits. Aust J Agric Res 54, 149-58

Savas T, Yurtman Y, Karaagac F, Köycü E (2001) Effect of intensive group condition and sex on the oral stereotypes and some behaviour traits in fattening lambs. Arch Tierz 44, 313-22 [in German]

Sawalha RM, Snowder GD, Keown JF, Van Vleck LD (2005) Genetic relationship between milk score and litter weight for Targhee, Columbia, Rambouillet and Polypay sheep. J Anim Sci 83, 786-93 
Strittmatter K (2001) The behaviour of sheep of different breeds on pastures recultivated after mining. Arch Tierz 44 Special Issue, 224-9 [in German]

Trillat G, Boissy A, Boivin X, Monin G, Sapa J, Mormende P, Neindre LP (2000) Relations entre le bien-etre des bovines et les caracteristiques de la viande (Rapport definitif-Juin). INRA, Theix, France, 1-33

Tuchscherer M, Manteuffel G (2000) The effect of psycho stress on the immune System. Another reason for pursuing animal welfare (review). Arch Tierz 43, 547-60 [in German]

Voisinet BD, Grandin T, Tatum JD, O'Connor SF, Struthers JJ (1997) Feedlot cattle with calm temperaments have higher daily gains than cattle excitable temperaments. J Anim Sci 75, 892-6

Received 16 April 2009, accepted 26 January 2010.

Corresponding author

FERENC PAJOR

email: pajor.ferenc@mkk.szie.hu

Szent István University, Faculty of Agricultural and Environmental Sciences, Institute of Animal Husbandry H-2100 Gödöllő, Páter K.1. , Hungary 